\title{
The Integration of Character Value in English Lesson Planning With Workshop Strategy on Tourism High School
}

\author{
Kammer Tuahman Sipayung \\ English Language Education \\ Faculty of Teacher Trainning, Universitas HKBP Nommensen \\ Medan, Indonesia \\ e-mail: Kammertuahmansipayung@gmail.com
}

\begin{abstract}
The objective of this study to improve the teachers competence on integrating character based on lesson plan. Workshop is one method that the researcher did to achive the aim. This research is school action research with quantitative and qualitative design. The data of this reseach are teachers' competence in form of score (quantitative) and the teacher atitude (qualitative). The population of this research were English Teachers from vocational school, however the sample are tourism English Teacher (Purposive sampling). This research was conducted with two cycles. This research shown that, workshop can improve teachers' competence to integrate value of character in lesson plan. In addition to that, there was an improvement of teachers' atitude. This improvement can be seen from cycle one (4 teachers: good, 6 teachers: average, 12 teachers: poor) and two (20 teachers: good, 2 teachers: average) and also their entusiasm.
\end{abstract}

\section{Keywords-Tourism, Competence, Character value}

\section{INTRODUCTION}

The purpose of our goverment through 2013 curricullum is to craete good character on students. It is occured since most remote villages and big cities in Indonesia, the symptoms have come to a very disturbing extent, such as a fight mass, parents kill her own child, husband kills his wife and vice versa, teen fights, fighting between learners and between schools, rampant corruption, social sensitivity barren and various other cases of moral de- cadence [1]. Whole teachers in Indonesia play a crucial role to achive the aim of government on education. Educational experts generally agree on the importance of efforts to increase the intensity and quality of the at titude and character education in formal education [1]. Good character can be achive in learning and teaching process through integrating the value of character in lesson planning. This integration can be applied to all subject.

Generally, there are three major activities in teaching and learning process. They are planning, acting and evaluating. Learning theories and information literacy standards should be used as the foundation of all information literacy learning design and activities [2]. It means that teacher need to prepare literacy information as teaching materials which able to provide good character in major activities of teaching-learning process. In other words, the value of character can be conducted in the classroom from the opening activity, core activity and closing activity. Through these activities there is a changes on students. The changes is called transformative teaching [3].

In this article, the researcher focus on investigating the English for tourism lesson plannig. In the observation, the researchers found most lesson planning which is made by the English for tourism teachers were lacking on integrating character value on lesson planning. [4] state that it is hard for them even to design the lesson plan before teaching. Budianto, 2014 in [4] stated that English teachers have enough conceptual understanding regarding the new curriculum but they cannot perform well in the level of implementation due to limited time allocation for English subject in senior high school level. It is a great reason for the researcher to conduct this research. This phenomenon will lead to the faillure of government education purpose. The comptence of attitudes expected is "respect and appreciate the teachings of their religion (as first core compe- tence)", "respect and appreciate the honest behavior, discipline, responsibility, caring (tolerance, mutual aid), mannered, confident, in interacting effectively with the social and natural environment in the range interaction and existence" (as second core competence) [1].

Based on the problem above, the researchers have a great desire to solve the problem. The researchers decided to applied workshop method to solve this situation. Practically, the significances of this research can achieve the goal of 2013 curricullum. Workshop strategy categorized sucsess to improve teachers' performance [5] and even competence [6] and on designing and acting the lesson plan.

\section{RELATED REVIEW}

\section{A. Curriculum 2013 and Character Based}

Etymologically, curriculum is derived from the Latin word "curriculae" which stands for "distance." Distance to indicate gap in education. Curriculum 2013 is one of the curricula which comes to add or even to replace the previous curriculum, school-based curriculum or KTSP (in school) or competence-based curriculum or KBK (in higher education) 
[7]. It is to indicate where the background of curriculum 2013. It is as an effort to solve the current national problem. The purpose of curricullum is to improve the quality of education in such country. Therefore, Indonesian curriculum has changed for eleven times since the establishment; 1947 Curriculum, 1964 Curriculum, 1968 Curriculum, 1973 Curriculum, 1975 Curriculum, 1984 Curriculum, 1994 Curriculum, 1997 Curriculum, 2004 Curriculum or Competence - based Curriculum, 2006 Curriculum or School - based Curriculum, and the latest is 2013 Curriculum [8]. The changes of curriculum occured since the needs of education field like attitudes, skill and knowledge which must be have by the next generation.

Reflection and refinement are the application of previous curriculum (school-based curriculum). It means that curriculum 2013 is the estensiom of school based curriculum in some components. To improve the quality of education, The implementation of curriculum 2013 are recomended by the government. The significance of curriculum 2013 is to create creative, affective and innovative young generation through well attitudes, skills and integrated knowledge. Curriculum is a set of plans and guidance for implementing the teaching and learning activities. Observing, questioning, experimenting, associating and communicating are creativity which is gain in curriculum 2013. This creativity is reffered to scientif approach.

In implementing curriculum 2013, in teaching process, teachers create the students become critical thinker, communicator, leader, collaborator and innovator. It is the characteristics of teaching and learning in the 21 st century. Core competence of language learning based on Minister of Education and Culture, No 22; 2016 is designed to provide experience in using English text to comprehand and apply factual, procedural and conceptual knowledge related to eye catching phenomena and events, through the activities of writing, speaking, reading and listening. The aim of text usage to develop value of attitude, religious and social. The realization of these values can be seen from the character of honest, discipline, responsibility, care (tolerance, mutual assistance) confident and courteus in natural environment.

Character education is the deliberate effort to help people understand, care about, and act upon core ethical values (Abourjilie, 2002: 9). The implementation of character education in the formal and informal institution is very important and urged to improve the quality of education. Kementrian pendidikan dan kebudayaan, 2013 declares that pouring the main target in the curricullum in 2013, namely the formation of attitudes and character young generation. The great problem of Indonesian in education is a set the values of attitude and character. Now a days, it is a main goal of Indonesian's education. Scientific approach is a strategy to achieve that aims (to create a good character and values). To achieve these goals, some experts propose various theories. Superka et.al (1967) in [1] recomended five typologies that inculcation of values education, moral development, analysis, value clarification, and action instructional approaches. It is to indicate that, the implementation of scientific approach is contradiction.

\section{B. English Lesson Planning and Workshop}

The planning of learning process covers syllabus and lesson plan which at least contain the learning objectives, learning material, instructional method, learning resources, evaluation on the learning result, according to Governmental Regulation Number 19 of 2005. In addition to that, the regulation of Ministry of National Education Number 41 of 2007 explained that lesson plan is elaborated from syllabus as to direct the learning activities of learner in an attempt to accomplish the intended basic competency. A lesson plan then become the guidance for teachers when applying english subject in the classroom [9]. Based on explanantion above, it can be concluded that lesson plan is a plan of learning activities. The constrain of integration of character value on lesson plan become bigger. There is a need for English teacher to design the learing activities.

There are six main elements on lesson plan namely, goal (s), objectives, materials and equipment, procedures of teaching- learning process, evaluation, and extra-class work [10]. Teachers can add another element to support the sixth main element. The sixth elements on lesson plan like a compas in teaching-learning process. The lesson plan arranged by teachers should be based on the syllabus which should be within the curriculum [11]. In addition to that, lesson plan is change since the changes of curriculum. That is why, Teacher in this term ESP for tourism teacher need to be aware to arrange the lesson plan based on curriculum 2013. The characteristic of lesson plan based on curriculum 2013 has a different characteristics with the previous lesson plan. It means that lesson plan must be based on curriculum 2013 component especially in term of integration of character value on lesson plan.

Workshop in school action is directly integrated to the theory and practice. This is called as learning by doing through micro teaching. This strategy is good to apply to make them active and creative. This strategy is able to build the self confidence, responsibility and emotional relationship among of ESP teacher.

\section{RESEARCH METHOD}

This research is used cycle treatment. Every cycle consist of planning, acting, observing and reflection. The treatment above was implemented to improve ESP Teachers to integrate character value on lesson planning. In planning section, the researcher design the plan in form of goal, materials and evaluation. In the action stage, the researcher applied the plan. In observing stage, the researcher pay attantion on their result in integrating the value of character on lesson plan. In the last stage, the researches evaluate through reflecting the aspect which lead the failure. Finally through reflection, the researcher went to cycle two by re-planning, re-acting, reobserving and reflection. This activivies were done till workshop strategies categories sucsess. The treatment of school action research can be observed in the following figure. 


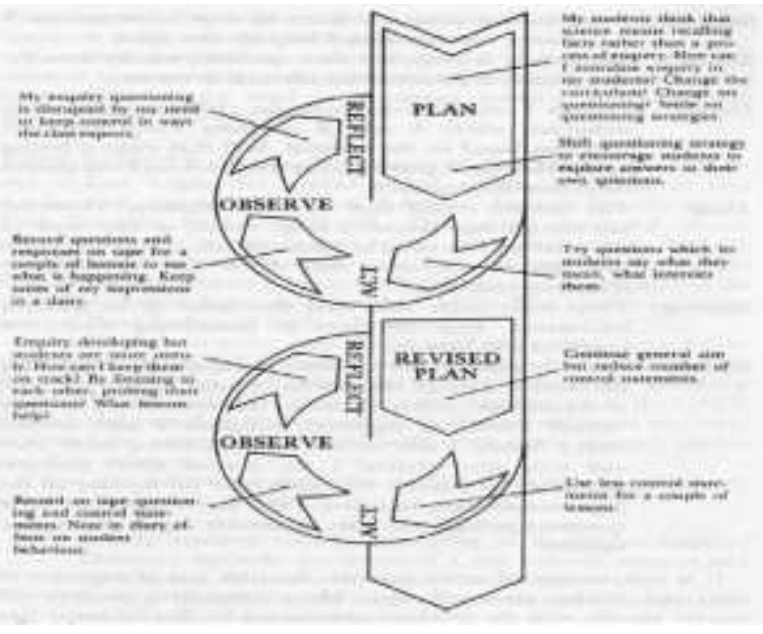

Fig. 1. The Action Research

This research was conducted with quantitative and qualitative design with school action research. The data of this research are teachers' score (quantitative) in designing and integrating lesson plan on character value. The next data (qualitative) is the result of observation and interview. The source of data were from lesson plan, observation sheet and interview. The population of this research were English Teacher from vocational school at Pematangsiantar The sample of this data are English for tourism. They are from SMK USI and HKBP. The sample are eight teachers. In order to figure out the finding of this research, the researchers conducted two cycles. Each cycles consist of four activities, such as planning, action, evaluation and reflection.

Some steps were implemented in this research. the first was setting measurement basis. This step was done to measure the competence of teacher in integrating character value on lesson planning. The result of this, shown which aspects that really to improve. The second step was evaluating. This step was done by crosschecking the lesson plan after treating with some techniques on workshop. The next step was comparing the bench mark with the previous step. The final step were isolating the competence need to improve and conducting collective action to make the plan come true.

The lesson plan of teacher to indicate their competence on designing lesson plan were collected. It was called as observation. Before starting on the first cycle, the ESP for tourism were asked to fill the questioner to measure their competence. It is done in the first and the second cycle to know the progress.

\section{FINDING AND DISCUSSION}

After analyzing the data on teachers competence which realized on integrating character value on lesson plan. The finding of this research can be observed in the following table.

TABLE 1. FINDING

\begin{tabular}{|l|c|c|l|}
\hline \multirow{2}{*}{ No } & \multicolumn{3}{|c|}{ Teacher Competence } \\
\cline { 2 - 4 } & Cycle I & Cycle II & Category \\
\hline 1 & 4 & 20 & Good \\
\hline 2 & 6 & 2 & Average \\
\hline 3 & 12 & 0 & Poor \\
\hline
\end{tabular}

The table above shown us that there is an improvement on ESP Teachers' competence on integrating character value on lesson plan. In the first cycle, there are only four ESP teacher which categorized good however in the second cycle become twnty. Categorized average in cycle $I$ is 6 become 2. In the cycle two there is no categorized poor. It's to indicate the strategy of workshop can improve the ESP for tourism at SMK Pariwisata USI and HKBP on integrating character value in lesson plan. The integration of character value on lesson plan of ESP for tourism through workshop activities have a positive impact. It can be seen from their pedagogic competence in designing lesson plan based on the need.

\section{ACKNOWLEDGMENT}

The researcher would like to deliver a great thaks to KEMENRISTEKDIKTI for the fund based on the number SP DIPA-042.06.1.401516/2018 which really helpful to conduct this reaserch.

\section{REFERENCES}

[1] B. Muhamad and S. Saparahayuningsih, "An Attitude and Character Instructional Development Based on Curriculum 2013 in Elementary School,” no. February, pp. 269-277, 2016.

[2] L. Wang, "Feature," Library (Lond)., vol. 47, no. 2, pp. 149-158, 2007.

[3] N. M. Umaya, "TRANSFORMATION ON TEACHING AS A COMPETENCE," in International Conference on Research in Education, 2017, pp. 347-363.

[4] A. Y. Wahyudin and D. Sukyadi, "A Closer Look at the Implementation of the Curriculum 2013 in Indonesia: Should the Scientific Approach Be Used in EFL Classroom?," Rangsit J. Educ. Stud., vol. 2, no. 2, pp. 56-70, 2015.

[5] P. J. Vol, T. M. I. R. Qur, and S. M. A. T. M. I. Roudlatul, "Premise Journal Vol 4 No 2 October 2015 ISSN: 2442-482x (cetak)ISSN: 977244248DD3 (electronic)," vol. 4, no. 2, pp. 21-31, 2016.

[6] J. Nurkamto, "International Conference on Education and Language," in The Development of Guidelines for the Arrangement of CharacterBased English Language Lesson Plan for the Teachers of Junior Secondary Schools in Surakarta City: A Preliminary Study, 2013, vol. I, pp. 23-28.

[7] S. Tegamuni and K. N. Ugu, "The Teacher's Problem in Implementing Curriculum 2013 at State Senior High School 3 of West Halmahera," Langua-Journal Linguist. Lit. Lang. Educ., vol. 2, no. 1, pp. 33-38, 2019.

[8] U. Nur and L. Sulistyani, "The Importance of Needs Analysis in a Language Curriculum Development: An Evaluation to 2013 Curriculum," no. November, pp. 22-23, 2018.

[9] S. Syamsia and S. Tegamuni, "The Implementation of Curriculum 2013 in English Subject at SMA Negeri in Ternate," Langua-Journal Linguist. Lit. Lang. Educ., vol. I, no. 1, pp. 73-82, 2018.

[10] Marjito, "How To Plan a Lesson (a Case Study At Stmik Mardira Indonesia)," J. Comput. Bisnis, vol. 3, no. 2, pp. 93-99, 2009.

[11] N. D. Handayani, "ASSESSING ABILITY IN ARRANGING LESSON PLAN (BASED ON 2013 CURRICULUM) OF THE SIXTH 
SEMESTER STUDENTS OF EESP OF MAHASARASWATI

Bakti Sar., vol. 2, no. 1, pp. 88-93, 2014. 